\title{
The effect of awareness and incentives on tax evasion ${ }^{*}$
}

\author{
Annette Alstadsæter \\ University of Oslo \\ annette.alstadsater@medisin.uio.no \\ Martin Jacob \\ WHU - Otto Beisheim School of Management \\ martin.jacob@whu.edu
}

This version: March 2013

\begin{abstract}
We examine the role of tax incentives and tax awareness on tax evasion. We are able to observe tax evasion of business owners in rich Swedish administrative panel data. During the period of 20062009 , around $5 \%$ of tax returns overstate a claimed dividend allowance even after the tax authority has approved the returns. Tax awareness decreases and complexity increases the likelihood of misreporting. Our results indicate that some of the observed misreporting could be accidental while some misreporting is deliberate tax evasion. We identify a positive and significant effect of tax rates on tax evasion by exploiting a large kink in the tax schedule.
\end{abstract}

Keywords: Tax evasion, tax compliance, misreporting, tax awareness, income taxation

JEL Classification: H26, H24, D14

We thank Jan-Erik Bäckman, Kay Blaufus, Sebastian Eichfelder, Igor Goncharov, Ingemar Hansson, Jochen Hundsdoerfer, Claus Kreiner, Christian Leuz, Henry Ohlsson, Michael Overesch, Agnar Sandmo, Thorsten Sellhorn, Altin Vejsiu, and seminar participants at the University of Frankfurt am Main, WHU - Otto Beisheim School of Mangement, the Nordic Workshop on Tax Evasion in Stockholm, and the Swedish Tax Authority Skatteverket for helpful comments and suggestions. 


\section{Introduction}

Taxpayers try to minimize taxes through legal or illegal means. At the same time, tax authorities attempt to improve compliance, detect tax evasion, enforce tax rules, and close unintended loopholes for legal tax avoidance. ${ }^{1}$ However, not everyone with access to tax minimization actually choose to participate in such activity (Kleven et al., 2011). A growing literature emphasizes tax awareness as an explanation as to why some taxpayers engage in legal tax avoidance activities while others do not. The taxpayer's awareness of tax rules depends on the salience of taxes (Chetty, Looney, and Kroft, 2009; Finkelstein, 2009). Slowness in adoption to changing income levels or procrastination may also explain why not all individuals respond to tax incentives (Jones, 2012, Kopczuk, 2012). Further, the ability to process the available tax information varies across individuals and may depend on the flow of information through informal networks (Alstadsæter, Kopczuk, and Telle, 2012, Alstadsæter and Jacob, 2013). Nonpecuniary factors such as morale, norms, social conscience, and attitudes towards government can all explain non-participation in tax evasion (Andreoni, Erard, and Feinstein, 1998, Slemrod, 2003, and Sandmo, 2005).

While most of these arguments relate to the conscious decision to evade taxes, some taxpayers may accidently file erroneous tax returns. Complexity of the tax system can increase unintended as well as intended non-compliance (Kopczuk, 2006, Slemrod 2007). The mere design of the tax return form can result in tax evasion if taxpayers have difficulties to comply with the rules. At the same time, taxpayers may deliberately take advantage of complex rules and tax forms if they perceive a low probability of detection is low. Therefore, the organization of the tax administration and the strength of tax enforcement additionally affect non-compliance of taxpayers. For example, if control routines of tax authorities are not adjusted following a tax reform that changed incentives, neither accidental nor intended tax evasion can be detected. In this study, we are interested in the effects of complexity, tax awareness, and tax incentives on tax evasion.

The general challenge of any empirical studies on tax evasion is the lack of appropriate data and an unobservable dependent variable. When using administrative data, the extent of tax evasion the unknown as tax evasion is defined as the difference between true and (under)reported income. In contrast to other studies, we have a unique setting to empirically study tax evasion and non-compliance. We directly observe systematic errors in tax returns of

1 In practice there is a blurry line between legal tax avoidance and illegal tax evasion due to unclear regulations lacking enforcement and tax agencies' focus on particular types of transactions (Slemrod and Yitzhaki, 2002). 
business owners after the tax authority has approved the data. By merging information across taxpayers, we are able to uncover a specific type of tax evasion in administrative data.

We use a large Swedish micro panel dataset for the years 2006-2009 with information on income, tax rates, and other socioeconomic variables of individuals. This panel covers the population of all tax returns of all active Swedish closely held corporation (CHC) owners, including the corresponding corporate tax returns. The advantage of our tax evasion measure is that the extent of evasion is observable. It is defined as the difference between an the observed claimed allowance and the legal maximum as defined in the tax code. We are interested in the dividend allowance which determines the amount of dividends from CHC that active owners receive at a preferential tax rate. This dividend allowance is defined as a fixed amount per firm in a fiscal year. ${ }^{2}$ The allowance is allocated across owners according to their share in equity. As the dividend allowance is claimed by each shareholder individually, they may outrightly claim a dividend allowance above their actual share. By overstating this dividend allowance, taxpayers can illegally re-classify labor income as dividend income to reduce the total tax burden.

During our sample period, about 5\% of active owners overstate the dividend allowance and, thus, evade taxes. ${ }^{3}$ However, as $60 \%$ of the individuals overstating the dividend allowance do not generate tax benefits from overstating the dividend allowance (based on the current tax status), some of the observed tax evasion in the tax return appears to be accidental. One important fact is that the tax administration did not systematically control for the type of tax evasion. The tax authority did not merge information across shareholders to test if owners jointly claim a dividend allowance above the legal maximum per firm. We find that, even though the percentage of tax evaders is decreasing over time, the majority of the overstated dividend allowances is corrected by the taxpayer himself and not by the tax authority. In this paper, we interested in three questions. First, who overstates the dividend allowance and what characteristics increase the likelihood to evade taxes? Second, is overstating the dividend allowance driven by the tax benefit from re-classifying labor income as dividend income? Third, what drives the dynamics of detecting the overstated dividend allowance?

We first develop a simple model of overstating the dividend allowance with endogenous probability of detection and a risk-neutral taxpayer based on the tax evasion model by Allingham and Sandmo (1972). Our model shows that if the tax rate on dividends is below the

2 This allowance is used by $80 \%$ of the CHC owners. Owners can choose an alternative calculation method where the dividend allowance depends on equity and wages paid by the corporation.

3 Even though overstating the dividend allowance only results in a penalty of the overstated allowance has been utilized for dividend payments that same year, it is regarded as tax evasion by the Swedish tax administration and requires correction upon detection. 
tax rate on labor income, overstating the dividend allowance can increase net-of-tax income. This effect can, however, be negative if the detection of the overstated dividend allowance additionally unveils underreported taxable income. Hence, if the probability of detection is high and if the taxpayer underreports taxable income, individuals may not overstate the dividend allowance even if the tax rate on dividends is below the tax rate on labor income. In contrast, if the tax rate on dividends is above the tax rate on labor income, overstating the dividend allowance ultimately reduces net-of-tax income and would be irrational.

We empirically test the effect of firm-level and individual-level characteristics on the probability of evading taxes. Our results suggest that the likelihood that a taxpayer overstates the dividend allowance is affected by complexity and tax awareness. For example, the likelihood of overstating the dividend allowance increases in the number of owners of a firm, in the number of firms an individual owns, and if owners live in different municipalities. In contrast, paying out dividends increases the probability of detection and thus reduces the likelihood to overstate the dividend allowance. Variables related to awareness and financial literacy, such as higher education, being born in Sweden, and income, reduce the probability of evading taxes. We also control for the purpose of the firm. Alstadsæter and Jacob (2013) show that some CHCs such as holding, shell, and low-turnover corporations are used for (legal) tax avoidance. We find that the probability of overstating the dividend allowance is lower if the firm is used for legal tax avoidance. This finding indicates that illegal tax evasion and legal tax avoidance are not used as complementary ways of tax minimization.

Second, we are interested in a causal effect of tax rates on tax evasion. The Swedish tax rate schedule offers a suitable setting for identifying the predicted effect of tax rates on tax evasion from our model. If an individual is subject to the state tax of $20 \%$, the dividend tax rate is below the income tax rate on labor income. This tax wedge creates an incentive to overstate the dividend allowance. If the individual is not subject to the state tax, he has no tax incentive to re-classify labor income as dividend income and to overstate the dividend allowance. That is, around the cutoff of the state tax, the incentive to evade taxes changes. To identify the tax rate effect, we use local linear regressions with very narrow ranges of SEK 1,000 and SEK 500 (about USD 136 and USD 68) around this kink in the tax code. As observable characteristics are smooth around the kink, the identification stems only from differences in the tax rate. In line with our theoretical predictions, we find that crossing state tax threshold increases the likelihood of overstating the dividend allowance by 2.0 percentage points, or about $40 \%$ of the unconditional sample mean. We characterize this as intentional tax evasion as the decision to evade taxes is driven by the tax advantage. We find that this tax rate effect, i.e. deliberate tax evasion, is stronger for tax aware individuals and for less complex tax returns. In contrast, tax 
unaware individuals as well as individuals with more complex tax returns do not respond to the tax incentive. Taken together, our findings suggest that lack of awareness and complexity can result in accidental tax evasion while tax benefits drive intended tax evasion behavior.

Finally, we analyze the dynamics of detection. We can distinguish two cases in the data. First, the taxpayer himself changes his behavior and complies with the tax rules after having overstated the dividend allowance for some years (Self-Correction). Second, the tax authority detects evasion and automatically corrects prior year's outrightly claimed dividend allowance. Surpirsingly, about $70 \%$ of the mistakes are corrected by the taxpayer. Only $30 \%$ are corrected by the tax administration. This observation relates to the importance of changing enforcement and control strategies following the implementation of new tax rules. We use a duration model to analyze the dynamics of detecting the overstated dividend allowance either by the taxpayer or by the tax authority. Our results suggest that complexity in compliance increases the time until detection. If a firm has many owners, it requires more effort to coordinate both, the preparation of the tax returns and their audit. Further, the time until self-correction decreases for individuals with higher degrees of tax awareness. This suggests that inertia of taxpayers is weaker for tax aware individuals (Jones, 2012)

Our results have four main implications. First, our results relate to tax enforcement strategies and the quality of tax compliance in general (e.g. Sánchez and Sobel, 1993; Chander and Wilde, 1998; Boadway and Sato, 2009; Alm, Jackson and McKee, 2009; Bigio and Zilberman, 2011). Our results point toward the usefulness of automatic, computer-based plausibility checks. ${ }^{4}$ Second, when designing tax reforms, policy makers need to update enforcement and audit strategies to meet new incentives and new sources of mistakes. For example, Christensen, Hail, and Leuz (2012) show that the liquidity benefits of adopting international financial reporting standards for reporting purposes is limited to those countries that also changed the enforcement. Third, at least some of the observed tax evasion appears to be accidental. Lack of tax awareness and complexity of the tax code can result in accidental tax evasion through overstatement of the dividend allowance. And fourth, tax forms and control routines should be designed in parallel by tax officials who are aware of tax incentives and changes in such.

The remainder of the paper is organized as follows. Section 2 presents the institutional background on the tax system and provides a definition of tax evasion through overstating the

4 In our case, the tax administration could have identified the type of tax evasion from the beginning on if they had applied a plausibility check similar to our calculation method. One practical implication of our paper is that the Swedish tax administration reconsidered their control strategies and now checks dividend allowances across individuals according to the simple method presented in our paper. 
dividend allowance. In Section 3, we develop a simple model of overstating the dividend allowance. Section 4 describes the data, variable definitions, and estimation strategy. In Section 5, we present results on tax evasion. Section 6 analyzes the dynamics of detecting overstated dividend allowances. Section 7 concludes.

\section{Institutional Background}

\subsection{The Swedish tax system and tax treatment of closely held corporations}

Sweden has a dual income tax with a progressive tax on labor income and a proportional tax on capital income. The progressivity in the tax on labor income is achieved through a municipality tax of on average $31.5 \%$ and two levels of state taxes of $20 \%$ and $5 \%$ that apply at different thresholds. In addition, social security contributions of 32\% apply to all wage payments on employer level. These contributions generate substantial benefits, such as health care, unemployment benefits, and future pensions. Above a certain threshold the social security contributions stop generating benefits (see column (4), Table 1). We thus consider these contributions as insurance and benefit contributions rather than a tax below this threshold. We consider them as a tax above the cutoff. Table 1 provides an overview over the development in marginal tax rates and thresholds for the two levels of state taxes and social security contributions for our sample period 2006-2009.

\section{[Insert Table 1 about here]}

Table 1 also presents the combined dividend tax rate $\left(\tau_{d}\right)$ which consists of the corporate income tax of $28 \%$ (26.3\% in 2009) and the dividend tax rate for closely held corporations at the individual level of $20 \%$. The difference between the marginal tax rates on labor and capital income creates a natural incentive for individuals subject to the state tax to re-classify wage income as dividend income. Alstadsæter and Jacob (2013) show that informed, highly-taxed individuals establish closely held corporations with low turnover to legally benefit from the tax difference between $\tau_{d}$ and $\tau_{i}$. If earned income is below the threshold for the first-level state tax (column 2, Table 1), $\tau_{i}$ is below $\tau_{d}$. That is, labor income is taxed at lower rates than dividend income. As soon as the earned income is subject to the first level of the state tax, the combined tax rate in dividends is below the income tax rate $\left(\tau_{i}>\tau_{d}\right)$ and individuals have an incentive to reclassify labor income as dividend income.

To reduce this type of income shifting of firm owners, the Swedish government has implemented the so-called 3:12 rules. The purpose of these rules is to split the profit of a corporation into a capital income component and a labor income component. According to these 
rules, dividends to active owners ${ }^{5}$ of closely held corporations ${ }^{6}$ are only treated as dividends for tax purposes within the dividend allowance. Dividends in excess of the dividend allowance are taxed as labor income. The dividend allowance is a function of equity and wage costs of the corporation (general imputation method). The allowance is determined at the shareholder level for each firm and is allocated across active shareholders according to the ownership share in the corporation. Any unused dividend allowances are carried forward with interest. In 2006, the 3:12 rules were reformed to foster entrepreneurship and growth of closely held firms. The reform included a reduction in the dividend tax rate from $30 \%$ to $20 \%$, an increase in the dividend allowance from the general imputation method, and an introduction of an optional, fixed dividend allowance per corporation (the simplification rule-Förenklingsregeln). In this paper we focus on this optional, fixed dividend allowance and tax evasion through overstating this allowance. One reason to implement this rule was to simplify compliance. The dividend allowance according to the simplification rule is independent of activity, equity, and employment in the firm.

\subsection{Identifying misreporting}

Each active shareholder in a closely held corporation has to file the K10-form. The K10form is a four page document where the shareholder calculates the dividend allowance for the particular corporation and reports dividends and disposal of shares of that closely held corporation. ${ }^{7}$ The K10-form is often filled out by the owner-manager himself. ${ }^{8}$ The active owner chooses the calculation method of imputing the dividend allowance under the 3:12 rules. That is, he chooses either the general rule or the simplification rule. Around $80 \%$ of active owners under the 3:12 rules choose the simplification rule to calculate the dividend allowance after 2006. In this case, taxpayers fill out only the first page of the document. ${ }^{9}$

Each active shareholder is entitled to a share of the fixed dividend allowance according to his ownership share in the CHC. Around the introduction of the new tax form that includes the new simplification rule in 2006, there was an ongoing process of reducing the number of

5 A shareholder is active if he contributes to profit generation in the firm to a considerable extent.

6 The tax law defines a corporation as closely held if four or fewer shareholders own at least $50 \%$ of the shares. Multiple family members count as a single shareholder. If these criteria are not met, the corporation is considered to be a widely held corporation. There are no differences in corporate taxation between widely and closely held corporations. Dividends from unlisted widely held corporations are taxed at 25\% since 2006.

7 The K10-form is available at the homepage of the Swedish tax authority (in Swedish for 2009 retrieved, December, 2012.): http://www.skatteverket.se/download/18.6d02084411db6e252fe80001510/211020.pdf.

8 We are, unfortunately, not able to observe if a tax consultant assisted in the preparation of the tax return. Owners of very large CHCs are likely to have tax consultants. In our empirical model, we include firm-size to control for this effect.

9 In case a taxpayer fills out both methods, the tax authority choses the method which results in the higher dividend allowance. We follow this approach when identifying whether a taxpayer uses the simplification rule. 
entries in tax forms. As a result, the shareholder is not asked to report his ownership share in equity in the K10-form after 2006. Instead, the shareholder only declares the resulting dividend allowance, $\boldsymbol{X}$, according to the following simple calculation (2006 value):

$$
(64950 \mathrm{kr}) \times \frac{\text { number of own shares }}{\text { number of total shares in the corporation }}=\boldsymbol{X} \text {. }
$$

Figure 1 shows the corresponding original excerpt from the K10-form of the simplification rule for fiscal year 2006. This is the first line in the K10-form. The taxpayer fills in the field 410 (this is $\boldsymbol{X}$ ) without explicitly stating his share in equity.

\section{[Insert Figure 1 here]}

While this appears to be pretty straight forward and fail-proof, it does require some minimum level of mathematics and ability to process information. There are some potential sources of mistakes into which we take a closer look. Let us consider an active shareholder who owns 50\% of the CHC's equity. Instead of his actual share of the dividend allowance, he could fill in the maximum annual fixed dividend allowance. As there is no shareholder register in Sweden, The tax authorities is not able to cross-check the implied ownership share. Consequently, taxpayers are able to overstate the dividend allowance. If this leads to any reduction in taxes in the present year, the Swedish tax authority imposes a penalty upon detection. In contrast, if there is no dividend payout in the year of overstatement, the authority does not impose a penalty upon detection. It simply corrects the "mistake". The taxpayer's advantage of the latter treatment of tax evasion is that the overstated dividend allowance can be carried forward with interest and can be utilized in later years when dividends are paid out. The possibility to accumulate and forward unused dividend allowance represents an option to expected future tax savings even if they do not generate any tax saving in the present period. By overstating the dividend allowance in the present period, the taxpayer reduces the present or future tax burden, depending on when (and if) dividends are distributed to the active owner. This type of tax evasion can more or less be done without a risk of penalty.

We illustrate the effect of overstating the dividend allowance in Table 2. We consider an individual with an ownership share of $50 \%$. Columns (2) to (4) show the tax evasion case of overstating the dividend allowance. In Column (5) to (8), we show the correct reporting. In case of evasion, the taxpayer effectively doubles the dividend allowance. The effect on the tax burden is substantial. Consider a taxpayer who is in the top marginal tax bracket and subject to an income tax of 56.6\%. If he receives a dividend (after corporate taxes) of SEK 396,717 which is equal to the accumulated overstated dividend allowance he pays dividend taxes equal to SEK $79,343(=396,717 \times 20 \%)$. In case of correct reporting, only half of the dividend payment is 
treated as dividends. The remaining part is taxed as labor income. ${ }^{10}$ This leads to a total tax burden of SEK $151,942(=198,358 \times 20 \%+198,358 \times 56.6 \%)$. Overstating the dividend allowance can thus have a substantial impact on the tax burden on of individuals.

[Insert Table 2 here]

\subsection{Detection and correction of overstated dividend allowance}

The tax administration in Sweden is organized in eight income tax regions with numerous tax offices in each of these regions. Each tax office covers on average three to four of the 290 Swedish municipalities. The selection for tax audits is centralized on a national level. The tax returns selected for audits are then distributed to the relevant local tax offices which perform the actual audits. During our sample period, there is no automatic control routine to check that the totally claimed dividend allowance on firm level does not exceed the maximum allowance. Therefore, it is not very likely that one auditor has access to information of other shareholders in the same firm.

We observe two different ways of detecting and correcting the overstated dividend allowance in the data. If a shareholder who overstates prior year's dividend allowance (year $t-1$ ) reports the allowance correctly in year $t$ without any changes in the accumulated dividend allowance, we label this as Self-Correction. That is, he changes his behavior but retains the outrightly claimed dividend allowance from prior years. Columns (2) to (4), Table 3 shows an example where overstating the dividend allowance is self-detected in 2008. In 2008, the correct amount of SEK $45,900(=50 \% \times 91,800)$ is declared. The previously overstated dividend allowances (in total SEK 159,195 in 2007) of the preceding years are not corrected. The taxpayer corrects the reporting on his own initiative without telling the tax administration.

In column (5) to (7), Table 3, we show cases which we label External Correction. In this case, the active owner who previously overreported the dividend allowance starts reporting it correctly. However, the accumulated dividend allowance from the previous year has been decreased by prior year's overstated dividend allowance. ${ }^{11}$ If the Swedish tax authority detects the overstated dividend allowance or is actively involved in the correction process, for example, in case of amended tax returns, it ultimately corrects the overstated dividend allowance of the current and of the preceding year. This is how we can distinguish between self-correction and

10 Note that paying out dividends in excess of the dividend allowance is not subject to social security taxes. Therefore, we can compare a $56.6 \%$ income tax rate with a $20 \%$ dividend tax rate.

11 When identifying overstatement of the dividend allowance, self-correction, and external correction, we take into account any dividend payments that reduce the dividend allowance. 
external correction. However, the adjustment of previously overstated dividend allowances does not go back two or more years in the data.

\section{[Insert Table 3 here]}

It is worth noting that we still may underestimate tax evasion in the data. We only have information on active owners of closely held corporation. If active owners claim a total dividend allowance which is not above the legal maximum, we define this as correct reporting. However, if there are passive owner(s) as well in this corporation, the active owners should in sum have claimed less than the maximum allowed dividend allowance. We cannot identify this in the data as neither we nor the tax authority has access to shareholder registers.

\section{A simple model of overstating the dividend allowance}

We formalize our predictions about evading taxes in a simple model. This model is based on the Allingham-Sandmo model where we assume risk-neutral taxpayers and an endogenous detection probability (see, Allingham and Sandmo, 1972; Yitzhaki, 1987; Slemrod and Yitzhaki, 2002; Sandmo, 2005; Kleven et al., 2011). In contrast to the standard approach in modeling tax evasion by underreporting true income, our measure of tax evasion refers to overstating the dividend allowance. This allowance defines the part of dividend income that is to be taxed at a proportional dividend tax rather than the progressive tax on wage income. If dividends are taxed at a lower rate than wage income, taxes are illegally minimized. However, it could well be that individual face an increase in the tax burden if they accidently overstate the dividend allowance in case the marginal labor income tax rate is below the dividend tax. Kleven et al. (2011), for example, find that some taxpayers overstate the true income in their tax returns.

In our model, we first consider a taxpayer with true income $\bar{y}$ that is equal to his taxable reported income $y$. We adjust the model and integrate the dual income tax. A part $\alpha$ of the income is subject to the income tax rate $\tau_{i}$. The remaining part $(1-\alpha)$ is subject to the dividend tax rate $\tau_{d}$. We define the effective overall tax rate on $\bar{y}$ as $\tau_{e}=\alpha \cdot \tau_{i}+(1-\alpha) \cdot \tau_{d}$. The taxpayer can overstate the dividend allowance by $e$. Overstating the dividend allowance by $e$ does not affect total income but leads to a change in the tax burden of $e \cdot\left(\tau_{d}-\tau_{i}\right)=e \cdot \Delta \tau$. Depending on the relation between dividend taxes and income taxes, overstating the dividend allowance can reduce or increase the overall tax burden.

With some probability $p$, the tax authority detects the overstated dividend allowance. We assume that in case of detection the dividend allowance is fully adjusted. We assume that the probability of detection is increasing in the overstated dividend allowance. As the dividend 
allowance is capped at the firm level, any overstatement of the dividend allowance above this cap $\bar{e}$ in one tax return is ultimately detected. Hence, $p(e)$ is a non-monotonic function which we define as $p=p(e)$ with $p^{\prime}(e) \geq 0$ and $p^{\prime \prime}(e) \geq 0$ if $0 \leq e \leq \bar{e}$ and $p(e)=1$ if $e>\bar{e}$. Put differently, as long as the claimed dividend allowance in one tax return does not exceed the legal maximum, the probability of detection is below one. If, however, the claimed dividend exceeds the annual limit per firm, the probability of detection is one. Therefore, the ability to evade taxes depends on the number of owners of a firm. Not everyone who may be willing to cheat has the ability to do so in our case (see also Kleven et al. 2011). Only owners of firms with multiple owners have access to this type of tax evasion and have the ability to overstate the dividend allowance.

In case an overstated dividend allowance is detected, the Swedish tax authority corrects the calculated dividend allowance, but does not necessarily impose a penalty. ${ }^{12}$ In case no dividends are paid out, there is no penalty. Therefore, we simplify our model and assume that individuals do not pay out dividends in the year over overstatement. In this case $\Delta \tau$ represents the present value of the expected change in the deferred dividend tax burden. While this reduces the value of evasion, it does not alter the sign of $\Delta \tau$. The risk-neutral taxpayer maximizes the following expected net-of-tax income:

$$
\begin{array}{ll}
u=(1-p(e)) \cdot\left[\bar{y}\left(1-\tau_{e}\right)+e \cdot \Delta \tau\right]+p(e) \cdot\left[\bar{y}\left(1-\tau_{e}\right)\right] & \text { if } 0 \leq e \leq \bar{e} \\
u=\left[\bar{y}\left(1-\tau_{e}\right)\right] & \text { if } e>\bar{e}
\end{array}
$$

We are interested in the first case. That is, the dividend allowance can be overstated with some probability that evasion remains undetected. The first term corresponds to the net-of-tax income in case the overstatement is not detected. The second term represents the net-of-tax income if evasion is detected. The first derivative of the net-of-tax income with respect to the overstatement $e$ is:

$$
\frac{\partial u}{\partial e}=\Delta \tau \cdot\left[1-e \cdot p^{\prime}(e)-p(e)\right] \quad \text { if } 0 \leq e \leq \bar{e}
$$

If $\Delta \tau>0$ and $1-e \cdot p^{\prime}(e)-p(e)>0$, an increase in $e$ increases the expected net-oftax income, that is, $\frac{\partial u}{\partial e}>0$. This simple model predicts that individuals should overstate the dividend allowance if the dividend tax exceeds the income tax on earned income up to the level

12 Niepelt (2005) presents an extended version of the Allingham-Sandmo model where he allows for duration dependent fines. While this could be of interest for the problem presented in this paper as individuals accumulate overstated dividend allowances over several periods, the Swedish tax authority does not impose duration dependent fines in practice. If at all, a potential fine only depends on the current overstated dividend allowance. 
of $\bar{e}$ and if the probability of detection is low. If $\Delta \tau<0$, any overstatement of the dividend allowance reduces net-of-tax income and tax evasion in the form of overstating the dividend allowance is very likely to be accidental.

There are two major concerns about this model. First, there are no penalties. Second, we ruled out the possibility that the taxpayer underreports his true income. Detecting an overstated dividend allowance could be a "red-flag" for the tax authorities. If the tax authority decides to audit the taxpayer as a consequence of the overstated dividend allowance, it could detect other sources of tax evasion. Equation (1) does not consider this possibility. We thus extend the model and consider a taxpayer with true income $\bar{y}$, taxable income $y$, and undeclared income $x \equiv \bar{y}-$ $y$. For simplicity, we assume that the probability of detection $p(e)$ does not depend on $x$. We follow Kleven et al. (2011) and assume that when underreported income is detected, the taxpayer pays the evaded taxes plus a penalty $\left(\delta \tau_{e} x\right)$. The taxpayer then maximizes the following net-of-tax income,

$$
\begin{array}{r}
u=(1-p(e)) \cdot\left[\bar{y}\left(1-\tau_{e}\right)+e \cdot \Delta \tau+\tau_{e} x\right]+p(e) \cdot\left[\bar{y}\left(1-\tau_{e}\right)-\delta \tau_{e} x\right] \\
\text { if } 0 \leq e \leq \bar{e}
\end{array}
$$

Again, we only consider cases where the claimed dividend allowance is below $\bar{e}$. The first derivative of net-of-tax income from equation (3) with respect to the overstatement $e$ can be written as:

$$
\frac{\partial u}{\partial e}=\Delta \tau \cdot\left[1-e \cdot p^{\prime}(e)-p(e)\right]-p^{\prime}(e) \delta \tau_{e} x \quad \text { if } 0 \leq e \leq \bar{e}
$$

This first derivative explains why not all taxpayers overstate the dividend allowance. The chance that an audit additionally unveils underreported taxable income reduces the optimal level of $e$. If $x$ and/or $\delta$ is sufficiently large, any overstatement of the dividend allowance may result in lower net-of-tax wealth even if $\Delta \tau>0$. As long as $\Delta \tau<0$, overstating the dividend allowance unambiguously reduces net-of-tax wealth.

From our model, we can formulate a simple prediction for the effect of tax rates on tax evasion. The sign of $\Delta \tau$ depends on the relation of $\tau_{d}$ to $\tau_{i}$. The advantage of our setting is that $\tau_{i}<\tau_{d}$ if the individual is only subject to the municipality tax. If the individual is subject to the state tax, $\tau_{i}>\tau_{d}$ and $\Delta \tau$ becomes positive. Therefore, we expect that the likelihood to overstate the dividend allowance is higher for taxpayers which are subject to the state tax of $20 \%$.

Our predicted effect further depends on the probability of detection. If the probability of detection is sufficiently high, even a taxpayer with a large tax incentive may not overstate the dividend allowance. For example, the probability of detection depends on the level of 
complexity. If a firm is owned and actively managed by more individuals, the complexity of an audit increases as the actual audit is performed on an individual basis. If auditors at different local tax authorities check these tax returns, the probability of detection decreases further. Even though the audit decision is made at a centralized agency, the actual audit is always performed at the local office. Therefore, any increase in the complexity of the compliance reduces the likelihood that tax authorities detect tax evasion.

\section{Data sample, variable definitions, and estimation strategy}

\subsection{Data}

We use the Firm Register and Individual Database (FRIDA) provided by Statistics Sweden. This panel data set is a combination of three main data sources: corporate tax statements, income tax statements, and the K10-form for owners of closely held firms. The corporate and individual data sets are full samples of all closely held corporations and their owners. The individual data contain information on income, demographics, and other socioeconomic variables. Due to unique identifiers, we can link information from the individual database and the corporate tax database to the population of K10-forms filed during 2006-2009. We include all observations where we can successfully link information of the corporation (from the corporate tax database) and of the individual (from the individual tax database) to the respective K10-form. The final sample consists of 576,916 K10-forms from 163,506 closely held corporations and 214,385 individuals during 2006-2009.

\subsection{Identifying tax evasion in the data}

We use a simple algorithm to detect overstated dividend allowances. We compute the claimed dividend allowance for firm $j$ in year $t$ using the simplification rule. We do so by summing up the claimed dividend allowances by all active owners of one firm. If the total claimed dividend allowance exceeds the maximum per firm, we flag each owner as having overstated the dividend allowance and set the dummy variable Failure to one. This classification follows Swedish tax laws according to which these cases are treated as tax evasion. If the claimed dividend allowance per firm does not exceed the maximum per firm, we set Failure to zero.

We observe overstated dividend allowances in about $5 \%$ of the filed $\mathrm{K} 10$-forms. The overstated dividend allowances amount to about SEK 3.3 bn. This figure does not take into account that the outrightly claimed dividend allowances can be carried forward with interest rates of about $7 \%$ to $8 \%$. Figure 2 plots the distribution of claimed dividend allowances in 
excess of the maximum amount for each year. We find that misreporting is highest in the year of the introduction of the new rule. Thereafter, tax authorities and/or taxpayers adapt to the new rules. Misreporting decreases but is still present. This is a first indication of inertia in the adoption of the new rules. The spikes in the distribution at the values of $1.5,2,3,4$, and 5 indicate that the majority of misreporting is due to firms with multiple owners. Each of the owners claims the full annual dividend allowance for the firm for himself without coordinating dividend allowances across owners.

[Insert Figure 2 about here]

\subsection{Estimation strategy and independent variables}

\subsubsection{The likelihood to overstate the dividend allowance}

We test the implications our theoretical considerations using linear probability model that contrasts the likelihood to evade taxes by overstating the dividend allowance against the correct statement of the dividend allowance. ${ }^{13}$ We specify the regression model as

$$
y_{i, j, t}=\alpha_{1}+\delta \Pi_{j, t}+\gamma \chi_{i, t}+\alpha_{t}+\alpha_{c}+\varepsilon_{j, t}
$$

where the dependent variable $y_{i, j, t}$ is an indicator variable for individual $i$, firm $j$ measured in year $t$, taking the value 1 if the dividend allowance is overstated, i.e. if individual $i$ evades taxes, and 0 otherwise. We use a set of firm-level and individual level control variables that are related to the incentive to evade taxes, awareness of tax rules, to complexity of tax compliance, and to the probability of detection.

The vector $\boldsymbol{\Pi}_{\boldsymbol{j}, \boldsymbol{t}}$ contains firm-level characteristics of firm $\boldsymbol{j}$ in year $t$. First, we include the number of active owners (Number Owners) and a dummy variable indicating whether the owners of a closely held corporation live in different states (Different Region). Both variables are proxies for complexity and relate to the costs of coordination across firm owners. If a firm is owned by many active owners which reside in various states, costs of coordination and of tax compliance increases. At the same time, the perceived probability of detection decreases. We thus expect the likelihood of overstating the dividend allowances to be higher when owners live in different states. Third, we include the age of the firm (Firm_Age) as a measure for inertia and slowness in adoption (Jones, 2012). Owners of well-established firms may have more difficulties to adapt new rules than individuals starting a new firm. In contrast, the effect of firm age on misreporting could be negative as the owners are more experienced in filing tax returns.

13 We run additional sensitivity tests and re-estimate the model using a probit model or a logit model. Results (not reported) are very similar. 
Fourth, we include a dummy variable Dividend Payout which is equal to one if the closely held corporation pays out a dividend in year $t$. We expect that paying out dividends reduces the likelihood of overstating the dividend allowance for two reasons. First, it raises taxpayer's awareness of the calculation of the dividend allowance. Second, the probability of detection increases as the tax administration more closely considers cases where dividend are paid out. ${ }^{14}$ Fifth, we include the natural logarithm of total assets (Ln(Assets)) as a measure for the firm size. We expect that smaller firms are more likely to overstate the dividend allowance as larger firms are more likely to have a tax consultant. Sixth, we include the profitability measure Return on Equity. The return to tax evasion is higher for profitable firms. Such firms have an incentive to overstate the dividend allowance. In contrast, we could observe the opposite effect. Less profitable firms may have incentives to increase the net-of-tax return of their company by illegal means. We, therefore, additionally include return on equity squared in the regression and expect a positive sign of the squared term. Seventh, we use the ratio of financial assets and cash holdings to total assets of the firm (Financial Assets) as a measure of passive firms. Finally, we include Shifter $\mathrm{CHC}$ which is a dummy variable indicating if the firm is a holding, shell, or low turnover corporation. These types of firms facilitate legal tax avoidance and income shifting following the 2006 tax reform (Alstadsæter and Jacob, 2013). The sign of Shifter CHC indicates whether illegal tax avoidance and legal tax evasion are substitutes or complements.

The vector $\chi_{i, t}$ contains controls for characteristics of individual $i$ in year $t$. We include the number of firms (Number Firms) in which the taxpayer actively participates. The number of firms is an individual-level control for complexity in compliance. At the same time, the number of firms is positively related to experience in tax compliance. Second, we control for the tax incentive. For example, Clotfelter (1983) and Feinstein (1991) document a positive relation between tax rates and tax evasion. In our sample, we measure the tax incentive through a dummy State Tax that is equal to one if the individual is subject to the state tax. In this case, the dividend tax rate $\tau_{d}$ is below the income tax rate on labor income $\tau_{i}$ and $\Delta \tau$ becomes positive. According to our model, we expect a positive effect of the state tax dummy on overstating the dividend allowance as the dummy variable reflects the sign of $\Delta \tau$ in our model. Further, we use the decile of the three-year average income distribution as income measure. We include a dummy for each decile (excluding the bottom decile) to account for a potential non-linear relationship between income and tax evasion. We additionally include variables related to tax

14 While one would expect that the calculation of the dividend allowance is always thoroughly checked by the tax administration when dividends are paid out, we find no empirical support for this expectation. The tax authority apparently does not automatically audit the calculation of the dividend allowance when dividends are paid out. We observe cases where outrightly claimed dividend allowances are utilized by taxpayers. 
awareness. If the observed type of tax evasion was not intended, tax aware individuals were less likely to overstate the dividend allowance. In contrast, if an individual is not tax aware, he may accidently overstate the dividend allowance. As proxies for tax awareness, we include the level of education, the type of education, experience (measured through age), and a dummy Born in Sweden which is equal to one if the individual was born in Sweden. For example, we expect that individuals with tertiary education and individuals who are born in Sweden are more tax aware and thus have a lower probability of overstating the dividend allowance.

We additionally include demographic controls for gender and marital status as well as year-fixed effects $\left(\alpha_{t}\right)$. We also include county-fixed effects $\left(\alpha_{c}\right)$ to account for differences across the 21 first-level administrative regions in Sweden. Our statistical inference is based is based on heteroskedasticity robust standard errors clustered at the individual level. Table 4 presents summary statistics and variable definitions of our sample.

\section{[Insert Table 4 about here]}

\subsubsection{Identifying tax incentive and tax awareness - local linear regressions}

The model from equation (5) includes the variable State Tax to test the effect of the tax wedge between dividend taxes and labor income taxes, $\Delta \tau$, on tax evasion. To establish empirical evidence on a causal relationship between tax rates and tax evasion, we use an alternative identification strategy. The Swedish tax rate schedule offers a suitable setting for testing the tax effect on tax evasion using a local linear regression. If an individual is subject to the additional state tax of $20 \%$, the tax rate on dividends falls below the income tax rate in labor income. $\Delta \tau$ from equation (4) becomes positive and the individual has a tax incentive to overstate the dividend allowance. Below the threshold, $\Delta \tau$ is negative and there is no incentive to overstate the dividend allowance. ${ }^{15}$ We take advantage of this major kink in the tax code and the change in $\Delta \tau$. We run a local linear regression to empirically test a causal relation between evasion and tax rates. This kink is salient to taxpayers (see Chetty, Looney, and Kroft, 2009; Finkelstein, 2009). Below the kink individuals pay municipality tax whereas individuals above the kink pay municipality and state tax. For example, Alstadsæter and Jacob (2013) use this kink to identify a tax effect on legal income shifting. We follow their approach and run the following local linear regression

15 One concern could be that overstating the dividend allowance influences labor income which determines whether an individual is subject to the state tax. This, however, can only happen if an individual distributes dividends in excess of the claimed dividend allowance. Owner-managers avoid paying these high dividends as it effectively increases the tax burden from $41 \%$ to over $66 \%$. We observe this in only $3 \%$ of all tax returns. Results are robust to the exclusion of these observations. 


$$
\begin{aligned}
& y_{i, j, t}=\beta_{1}+\beta_{2} \text { State Tax }_{i, t}+\mu_{j, t} \\
& y_{i, j, t}=\beta_{1}+\beta_{2} \text { State Tax } \text { Tax }_{i, t}+\vartheta \Pi_{j, t}+\xi \chi_{i, t}+\beta_{t}+\beta_{c}+\mu_{j, t}
\end{aligned}
$$

where $y_{i, j, t}$ is an indicator variable taking the value 1 if individual $i$ overstates the dividend allowance of firm $j$ in year $t$, and 0 otherwise. We choose very narrow ranges of SEK 1,000 and SEK 500 (about USD 136 and USD 68) around the state tax threshold to ensure that there are no differences between individuals above and below the threshold in observable characteristics. In fact, we detect no statistically significant differences in all variables of vectors $\boldsymbol{\Pi}_{\boldsymbol{j}, \boldsymbol{t}}$ and $\chi_{\boldsymbol{i}, \boldsymbol{t}}$ for individuals above and below the threshold. We are mainly interested in the $\beta_{2}$ coefficient. According to our model, $\beta_{2}$ is expected to be positive. We test the model with and without control variables. The specification in equation (6) includes no control variables. In equation (7), we control for firm-level controls $\left(\boldsymbol{\Pi}_{j, t}\right)$, individual level controls $\left(\chi_{i, t}\right)$, time $\left(\beta_{t}\right)$, and county-fixed $\left(\beta_{c}\right)$ effects. If our identifying assumptions hold, i.e. if individuals are randomly assigned across the kink, we should not observe differences in the $\beta_{2}$ cofficients across the two equations.

We additionally use local linear regressions to test the effect of awareness and complexity on the likelihood to evade taxes in two ways. First, we split the sample around the state tax threshold into more tax aware taxpayers (individuals born in Sweden) and less aware taxpayers (individuals born abroad). We do this to test whether tax awareness drives the effectiveness of the tax incentive effect. As the sensitivity of tax evasion to the tax benefit is related to intentional tax evasion, we expect that the positive effect of $\Delta \tau$ identified around the kink point is higher for people born in Sweden. Individuals born abroad have more difficulties in understanding the Swedish language than Swedish born taxpayers. If less tax aware individuals evade taxes accidently, they should not be responsive to the tax incentive.

Second, we are interested in the role of complexity in the effectiveness of the tax incentive. For this purpose, we split the sample into firms with either two active owners (lower complexity) or more than two active owners (higher complexity). ${ }^{16}$ The complexity of tax compliance increases in the number of taxpayers which need to align their dividend allowances across tax returns. Using these cross-sectional differences in complexity, we can test if complexity is related to intentional or accidental tax evasion. If taxpayers deliberately abuse complexity when evading taxes, the effect of crossing the cutoff for the state tax should increase

16 We use alternative sample split variables (number of firms, living in different regions). Results (not reported) are qualitatively similar when using these alternative variables. 
in complexity. That is, the effect of $\Delta \tau$ should be larger in the high complexity sample. In contrast, if complexity leads to unintentional tax evasion, the effect of tax rates in tax evasion should be more pronounced in the low complexity sample. It is an empirical question as to which of these two effects dominates.

\section{Empirical results on participation in tax evasion}

\subsection{The likelihood to overstate the dividend allowance}

Table 5 presents regression results for the OLS regression from equation (5). We present results for the firm-level variables $\left(\boldsymbol{\chi}_{\boldsymbol{i}, t}\right)$, individual-level variables $\left(\boldsymbol{\Pi}_{j, t}\right)$, and for the full set of independent variables. Our results suggest that the likelihood to overstate the dividend allowance is affected by complexity and the cost of coordination. The likelihood of tax evasion increases in the number of owners of a firm and if the owners live in different regions. The effects we find are economically significant. For example, an increase in the number of (active) owners by 1 increases the likelihood to overstate the dividend allowance by 3.67 percentage points - or about $73 \%$ of the unconditional sample mean of $5 \%$. In contrast, paying out dividends raises awareness of the potentially wrong calculation of the dividend allowance. We find that the likelihood of overstating the dividend allowance decreases by 1.25 percentage points or $25 \%$ of the unconditional mean if a firm distributes dividends. We further find that likelihood to overstate the allowance is higher for older as well as for smaller firms. We observe a significant effect of the squared term of return on equity. The resulting U-shape pattern for the return on equity effect reflects our expectation that the least profitable as well as the most profitable firms evade taxes. While less profitable firms may seek for illegal opportunities to increase the return, owners of highly profitable firms may overstate the dividend allowance as they enjoy large benefits in the form of tax reductions. Finally, the negative coefficient of Shifting CHC indicates that owners of CHC, which are designed for legal tax avoidance purposes, are less likely to also participate in illegal tax minimization. Being owner of a CHC designed for tax avoidance reduces the likelihood of overstating the dividend allowance by $12 \%$. This result is an indication that tax evasion and tax avoidance are not used as complementary ways of minimizing taxes. Put differently, taxpayers who avoid taxes are less likely to evade taxes. Our results for the firm-level variables are not affected by the inclusion of individual-level variables.

[Insert Table 5 about here] 
We next turn to our individual level variables. Our results suggest that variables related to complexity and awareness have a significant effect of the likelihood to overstate the dividend allowance. For example, the likelihood to overstate the dividend allowance increases in the number of firms. Even though experience with tax compliance increases in the number of firms, complexity of tax compliance increases if an individual actively participates in many firms. Our results suggest that an increase in the number of firms by 1 increases the likelihood of overstating the dividend allowance by 0.28 percentage points. We find that tertiary education and being born in Sweden reduces the likelihood of tax evasion. For example, if an individual is born Sweden, he has a 16\% lower probability of evading taxes. Likewise, having a university degree reduces the probability of overstating the dividend allowance by $24 \%$. This result indicates that tax aware individuals are less likely to evade taxes. Further, we control for income which is also related to tax awareness and financial literacy. Seven of nine of our income indicator variables have negative signs. In contrast to our theoretical model, we find ambiguous results for tax incentive coefficient (State Tax) depending on the inclusion of firm-level control variables. This could be interpreted as an indication that tax evasion is not driven by tax benefits ${ }^{17}$. However, the dummy State Tax could be correlated with other variables, for example, our income decile indicator variables. Using a better identification strategy by exploiting the sign change in $\Delta \tau$ around the major kink in the tax schedule, we shed more light into the causal effect of $\Delta \tau$ from our model on tax evasion (see below).

Finally, it appears as if there is learning effect. The likelihood to overstate the dividend allowance decreases over time as indicated by the decreasing year-dummy variables. Taken together, it appears that at least some of the observed tax evasion can be explained by lack of awareness and complexity. Not all individuals who overstate the dividend allowance actually benefit from tax evasion. In fact, the overall tax burden could increase for individuals subject only to the municipality tax. Summary statistics (not reported) show that $60 \%$ of businessowners who overstate the dividend allowance are not subject to the state $\operatorname{tax}(\Delta \tau<0)$. Still, some of the observed tax evasion can be due to deliberate tax evasion. Otherwise owners of highly profitable firms would not overstate the dividend allowance.

\subsection{Tax incentive and evasion: evidence from local linear regressions}

This section explores the causal relation between tax rates and tax evasion and analyzed the effect of tax awareness and complexity on intended tax evasion. If individuals respond to the tax incentive, we can interpret this as deliberate tax evasion. Taxpayers would then only

17 For example, Kleven et al. (2011) do also not find a significant effect of the tax rate on tax evasion. 
overstate the dividend allowance because of the tax benefit. Our model from Section 3 has a clear prediction: if the dividend tax is below the labor income tax, overstating the dividend allowance can increase the net-of-tax income. To test this prediction, we identify the effect of tax rates on tax evasion using local linear regressions around very narrow ranges of SEK 500 and SEK 1000 around the state tax threshold around that increases the marginal labor income tax rate by $20 \%$. Further, the sign of $\Delta \tau$ changes around the cutoff. This approach has several advantages. First, as individuals above and below the threshold are statistically not different from each other in observable characteristics, the identification stems only from the difference in $\Delta \tau$. Second, the tax rate increase is salient. The increase is due to the state level tax in addition to the municipality tax. Third, the threshold for the state tax changes each year. This time-series variation improves the identification of the tax effect. Table 7 reports the coefficient of the state tax dummy without control variables in Panel A and with control variables in Panel B.

\section{[Insert Table 6 about here]}

We find that crossing the state tax threshold significantly increases the likelihood of overstating the dividend allowance. The results are very similar for both ranges around the threshold. The economic effects are substantial. Crossing the state tax threshold increases the likelihood of overstating the dividend allowance by 2 percentage points - about $40 \%$ of the unconditional sample mean. Results are very similar when including controls (Panel B). This confirms that the sample is reasonably smooth around the kink as coefficient estimates are not affected by the inclusion of control variables, year-fixed effects, and county-fixed effects. Hence, some of the observed tax evasion is driven by the tax wedge between dividend taxes and labor income taxes. Individuals intentionally overstate the dividend allowance to benefit from lower dividend taxes as opposed to higher labor income taxes.

We are next interested in the role of tax awareness on intended tax evasion around the kink in the tax code. Our general argument is that lack of tax awareness leads to unintentional tax evasion. However, if tax benefits are the driving force behind intentional tax evasion, only individuals with a certain level of tax knowledge are sensitive to tax incentives. We use the variable Born in Sweden as a measure of cross-sectional differences in tax awareness. If knowledge of the Swedish language matter for the understanding of tax forms and codes, we expect that the effect of tax incentives on tax evasion is higher for individuals with profound understanding of the tax code. This variable is an exogenous proxy for tax awareness as the K10-forms along with other income tax forms are only available in Swedish. Therefore, we split the sample into taxpayers born in Sweden and individuals born abroad and re-estimate the effect of State Tax for each subsample.. The former group has a better and more natural understanding 
of the Swedish language than taxpayers born outside Sweden. ${ }^{18}$ The latter group is less tax aware and therefore less sensitive to the tax rate increase. Our results in Table 6, Columns (2) and (5) indicate that individuals with higher tax awareness, i.e. individuals that are born in Sweden, are more likely to evade taxes once they cross the state tax threshold $(\Delta \tau>0)$. This suggests that tax aware individuals respond to the tax incentive and deliberately overstate the dividend allowance. In contrast, we do not find an effect of $\Delta \tau$ on tax evasion in when using the sample of less tax aware taxpayers (Born abroad sample).

Finally, we are interested in the role of complexity in intended tax evasion. As complex tax compliance reduces the probability of detection, taxpayers may deliberately take advantage of complex situations. In contrast, complexity in compliance may result in accidental tax evasion. We therefore split the sample into two groups that differ in complexity. In Table 7, we present coefficient estimates for State Tax from local linear regressions for CHCs with two owners (lower complexity sample) and for CHCs with more than two owners (higher complexity sample). Our results indicate that complexity is related to accidental tax evasion. We find a positive effect of crossing the state tax threshold only in the low complexity sample. In the high complexity sample, crossing the state tax threshold does not affect the probability of overstating the dividend allowance. We test the robustness of our results and use the number firms and individual owns or if the owners live in different states as alternative proxies for complexity. Results are qualitatively similar. We only find a positive and significant effect in the low complexity group.

We conclude that some of the tax evasion is driven by the tax advantage of dividend income over labor income and tax awareness of the kink in the Swedish dual income tax. Individuals intentionally evade taxes once they have a tax incentive. Hence, not only legal tax avoidance (see Alstadsæter and Jacob, 2013), but also tax evasion through overstating the dividend allowance is driven by tax incentives and tax awareness. Further, as one requires business partners for this type of tax evasion, our type of tax evasion is another example that not everyone who may be willing to cheat has also the ability to do so (Kleven et al., 2011).

\section{Self-correction versus external correction of tax evasion}

\subsection{Identifying detection of tax evasion in the data}

We distinguish between two different types of detection which we label as selfcorrection and external correction according to legal consequences of detection by the tax

18 Unfortunately, we are not able to observe the country of birth due to secrecy reasons. 
administration (see above). We set the indicator variable Self-Correction to one if the individual corrects the dividend allowance himself, and zero otherwise. We only treat the case as selfdetection if the accumulated overstated dividend allowance from past years is not corrected. If the accumulated dividend allowance from $t-1$ is corrected as shown in columns (5) to (7) of Table 3, we set External Correction to one. Self-Correction and External Correction are mutually exclusive. Either the taxpayer or the tax authority detects the overstated dividend allowance. $^{19}$

Figure 3 summarizes the percentage of K10-forms with overstated dividend allowances in the preceding year and the percentage of cases that are detected. In 2007 , about $40 \%$ of the incorrect K10-forms of 2006 are corrected and are now declared correctly. Surprisingly, 70\% of these detected cases do not lead to a readjustment of the outrightly claimed dividend allowance. These cases are detected by taxpayers themselves without consequences. The remaining 30\% are corrections by the tax authority. This is a surprising result. This type of tax evasion is discovered by the authorities in only $12 \%(40 \% \times 30 \%)$ of all evasion cases even though an automatic check could have discovered all cases. Figure 3 also provides some first indications that the probability of detection with consequences (External Correction) decreases over time. First, the percentage of detected cases (self-corrected and externally detected) decreases from $40 \%$ in 2007 and 36.6\% in 2009. Second, the share of external corrections decreases from $30 \%$ in 2007 over $22 \%$ in 2008 to $20 \%$ in 2009 . That is, only $7.23 \%$ of overstated dividend allowances from 2008 are detected by the tax authorities. In case of detection, the vast majority does not have consequences on the accumulated dividend allowance.

[Insert Figure 3 about here]

\subsection{Time until detecting the overstated dividend allowance}

We are finally interested in the factors that affect the dynamics of self-correction-the taxpayer detects the mistake in calculating the the dividend allowance-versus external correction - the tax authority corrects the dividend allowance. We model the time until overstating the dividend allowance in the K10-forms is detected. We use a Cox proportional hazards model with time-varying covariates which we specify as:

19 It could be that some of the cases which we label external correction are based on the taxpayer's initiative. If he files an amended tax return, the tax authority would also correct prior year's overstated dividend allowance. We, however, have no information about amended tax returns. Yet, we know with certainty that our dummy SelfCorrection captures cases where the taxpayer does not contact the tax authority to inform them about his change in behavior. 


$$
\lambda(t)=\lambda_{0}(t) \exp \left(\theta \Pi_{j, t}+\eta \chi_{i, t}\right)
$$

where we use the time until self-correction and time until external correction as dependent variables. The advantage of a duration model is that it informs us about the dynamics of detecting tax evasion. As independent variables, we include the firm-level controls $\left(\boldsymbol{\Pi}_{\boldsymbol{j}, \boldsymbol{t}}\right)$ and individual level controls $\left(\chi_{i, t}\right)$. In this model, we expect variables related to complexity such as the number of owners or the number of firms to prolong the time until detection. In contrast, paying out dividends is expected to decrease the time until detection. Our statistical inference in the Cox hazards model is based on heteroskedasticity robust standard errors.

Table 7 presents regression results for the duration model from equation (8). We present results for the time to self-correction (Panel A) and time to external correction (Panel B). In general, our results point toward the importance of complexity, awareness, and also the tax incentive. For example, to uncover an overstated dividend allowance in a firm with many owners, the tax administration as well as taxpayers need to align tax returns across individuals. Consequently, we find that the time until overstating the dividend allowance is corrected increases in the number of owners for both, self-correction and external correction. In contrast, paying dividends raises awareness of how the dividend allowance is calculated and increases the probability of detection. We exactly find this result for self-correction as well as for external correction. The effect of profitability (Return on Equity) on detection is in the form of an inverted U-shape. Put differently, the least profitable and the most profitable firms are detected earlier than other firms.

We also observe interesting differences between self-correction versus external correction. For example, firm age increases the time until self-correction. This relates to the argument of inertia of taxpayers in responding to new tax rules and tax forms. In contrast, firm age decreases the time until external correction. Also, the number of firms, which one taxpayer owns, increases the time until self-correction while it decreases the time until external correction. The intuition behind this result could be a "red-flag" mechanism at the tax administration level. Once the tax authority detects the overstated dividend allowance in one firm of an individual, it also audits the K10-forms filed by the same owner for his other companies. We find different results for firm size across our two types of detection. Firm size increases (decreases) the time until self-correction (external correction). The latter could be the result of shorter audits cycles of larger firms.

Our individual level variables indicate that being subject to the state tax increases the time until self-correction. We find no effect on external correction. Our measures of tax awareness, for example, tertiary education and born in Sweden, decrease the time until self- 
correction. That is, individuals with higher degrees of tax awareness are quicker in correcting erroneous tax returns on their own.

[Insert Table 8 about here]

The comparison of the results from Tables 5 and 8 points toward the tension between the characteristics of individuals who overstate the dividend allowance and the determinants of detection. Not all factors that increase the likelihood of filing erroneous tax returns also decrease the time until detection by the tax authority, i.e. external correction. For example, while the number of owners is associated with a higher likelihood of overstating the dividend allowance, it does not decrease the time until external correction. In fact, it actually increases the time to detection. One implication of these observations is that effective "red-flag" mechanisms of tax authorities are required and should be based on empirical evidence of the characteristics of individuals evading taxes and on factors increasing the complexity of compliance. ${ }^{20}$

\section{Conclusions}

Tax authorities in many countries experience budget cuts while trying to maintain the quality and efficiency of tax revenue collection at the same time. The challenge is to improve tax compliance when costs of tax administration are reduced. Audits are costly and there are continuous efforts to automatize controls and audit selection of taxpayers. This paper shows that lack of awareness of the tax code and complexity in compliance affects tax evasion. We also find evidence for a causal relation between tax rates and observed tax evasion. The type of tax evasion, which we directly observe and identify in tax returns approved by the tax administration, is often corrected by the taxpayer himself. Complexity increases the likelihood of misreporting and decreases the probability of detection. The relatively low detection rate of tax authorities can be explained by slowness in adjusting enforcement and audit strategies following the implementation of new tax rules and tax forms.

Our findings have three main implications. First, when designing tax reforms that change incentives of taxpayers, policy makers should also adjust enforcement and audit strategies. Otherwise, a tax reform may have unintended consequences or the desired effect may not occur at all. This argument does not only apply to tax policy but to laws in general. For example,

20 We test the robustness of our results and estimate a multinomial logit model that contrasts the probability to overstate the dividend allowance, to self-correct or externally correct the overstated dividend allowance, or to correctly report the dividend allowance. We find similar results to the duration model. For example, the likelihood of self-correction or external correction as opposed to overstating the dividend allowance decreases in the number of owners or if owners live in different regions. In contrast, the probability of self-correction or external correction increases if the firm pays out dividends. We find no effect of tax rates on detection. 
Christensen, Hail, and Leuz (2012) show that the liquidity benefits of adopting international financial reporting standards (IFRS) is limited to those countries that also changed the enforcement of the accounting standards. Also, the mere threat of a stronger enforcement and higher detection risk or information about audit rules can effectively decrease tax evasion (Alm, Jackson, and McKee, 2009; Fellner, Sausgruber, and Traxler, 2011). Second, our results have broader implications for tax enforcement strategies (e.g. Sánchez and Sobel, 1993; Chander and Wilde, 1998; Boadway and Sato, 2009; Shaw, Slemrod, and Whiting, 2010; Bigio and Zilberman, 2011). It is necessary for effective control and compliance strategies of tax authorities to merge information across taxpayers and to use automatized, computer-based plausibility checks. Such a test would have automatically detected all overstated dividend allowances in our case. Third, at least some of the observed tax evasion in our paper appears to be accidental. Overall, only $40 \%$ of taxpayers actually benefit from the observed type of tax evasion given their current tax status. Complex tax rules and tax forms can trigger unintended tax evasion if mistakes are based on a lack of tax awareness and slowness in adapting to new rules. The main challenge for tax authorities is to distinguish between accidental tax evaders and those that deliberately evade taxes. And fourth, tax forms and control routines should be designed in parallel by tax officials who are aware of tax incentives and their changes. Easily understandable and well-designed tax forms provide information to taxpayers and can reduce accidental misreporting. Integrating such “easy-to-comply” tax forms in design of control routines enables increased automatized auditing by tax administrations. Also, reducing accidental misreporting, tax authorities can shift scarce auditing resources on detecting intentional tax evasion. Disentangling empirically unintentional and intentional tax evasion is a relevant and challenging avenue for future research, policy makers, and tax authorities. 


\section{References}

Andreoni, James, Erard, Brian and Feinstein, Jonathan S. (1998): Tax Compliance. Journal of Economic Literature, 36, 818-860.

Allingham, Michael G. and Sandmo, Agnar (1972): Income Tax Evasion: A Theoretical Analysis. Journal of Public Economics, 1, 323-338.

Alm, James, Jackson, Betty R., and McKee, Michael (2009): Getting the word out: Enforcement information dissemination and compliance behavior. Journal of Public Economics, 93, 392-402.

Alstadsæter, Annette and Jacob, Martin (2013): Who participates in Tax Avoidance? FAccT Center Working Paper No. 08/2012.

Alstadsæter, Annette, Kopczuk, Wojciech, and Telle, Kjetil (2012): Social networks and tax avoidance: Evidence from a well-defined Norwegian tax shelter. Mimeo, Columbia University.

Bigio, Saki and Zilberman, Eduardo (2011): Optimal self-employment income tax enforcement. Journal of Public Economics, 95, 1021-1035

Boadway, Robin and Sato, Motohiro (2009): Optimal Tax Design and Enforcement with an Informal Sector. American Economic Journal: Economic Policy, 1, 1-27.

Chander, Parkash and Wilde, Louis L. (1998): A General Characterization of Optimal Income Tax Enforcement. Review of Economic Studies, 65, 165-183.

Chetty, Raj, Looney, Adam, and Kroft, Kory (2009): Salience and Taxation: Theory and Evidence. American Economic Review, 99, 1145-1177.

Christensen, Hans B., Hail, Luzi, and Leuz, Christian (2012): Mandatory IFRS Reporting and Changes in Enforcement. SSRN Working Paper.

Clotfelter, Charles T. (1983): Tax Evasion and Tax Rates: An Analysis of Individual Returns. The Review of Economics and Statistics, 65, 363-373.

Feinstein, Jonathan S. (1991): An econometric analysis of income tax evasion and its detection. RAND Journal of Economics, 22, 14-35.

Fellner Gerlinde, Sausgruber, Rupert, and Traxler, Christian (2011): Testing enforcement strategies in the field: Threat, moral appeal and social information. Journal of the European Economic Association, forthcoming.

Fortin, Bernard, Lacroix, Guy, and Villeval, Marie-Claire (2007): Tax evasion and social interactions. Journal of Public Economics, 91, 2089-2112.

Finkelstein, Amy (2009): E-ZTAX: Tax Salience and Tax Rates. Quarterly Journal of Economics, 124, 969-1010.

Jones, Damon (2012): Inertia and Overwithholding: Explaining the Prevalence of Income Tax Refunds. American Economic Journal: Economic Policy, 4, 158-185. 
Kleven, Henrik, Knudsen, Martin, Kreiner, Claus Thustrup, Pedersen, Soren, and Saez, Emmanuel (2011): Unwilling or Unable to Cheat? Evidence from a Tax Audit Experiment in Denmark. Econometrica, 79, 651-692.

Kopczuk, Wojciech (2006): Tax Simplification and Tax Compliance: An Economic Perspective. In: Bridging the Tax Gap. Addressing the Crisis in Tax Administration, Edited by Max Sawicky, Washington, DC: Economic Policy Institute, 111-143.

Kopczuk, Wojciech (2012): The Polish business “flat” tax and its effect on reported incomes: a Pareto improving tax reform? Mimeo, Columbia University.

Lee, Kangoh (2001): Tax evasion and self-insurance. Journal of Public Economics, 81, 73-81.

Niepelt, Dirk (2005): Timing tax evasion. Journal of Public Economics, 89, 1161-1637.

Saez, Emmanuel, Slemrod, Joel B., and Giertz, Seth H. (2012): The elasticity of taxable income with respect to marginal tax rates: A critical review. Journal of Economic Literature, 50, 3-50.

Sánchez, Isabel and Sobel, Joel (1993): Hierarchical design and enforcement of income tax policies. Journal of Public Economics, 50, 345-369.

Sandmo, Agnar (2005): The Theory of Tax Evasion: A Retrospective View. National Tax Journal, 58, 643-663.

Shaw, Jonathan, Slemrod, Joel B., and Whiting, John (2010): Administration and Compliance. In: Dimensions of Tax Design. The Mirrlees Review. Oxford University Press. 11001162.

Slemrod, Joel B. (2003): Trust in Public Finance. In: Public Finance and Public Policy in the New Century, Edited by Sijbren Cnossen and Hans-Werner Sinn. Cambridge, MA: MIT Press, 49-88.

Slemrod, Joel B. (2007): Cheating ourselves: The economics of tax evasion. Journal of Economic Perspectives, 21, 25-48.

Slemrod, Joel B., Blumenthal, Marsha, and Christian, Charles W. (2001): Taxpayer response to an increased probability of audit: evidence from a controlled experiment in Minnesota. Journal of Public Economics, 79, 455-483.

Slemrod, Joel B. and Shlomo Yitzhaki (2002): Tax avoidance, evasion, and administration. In: Handbook of Public Economics, Volume 3, Edited by Alan J. Auerbach and Martin Feldstein. Elsevier. 1423-1470.

Yitzhaki, Shlomo (1987): On the Excess Burden of Tax Evasion. Public Finance Quarterly, 15, 123-137. 


\section{Figure 1: Excerpt from K10-Form for CHC Owners}

This figure shows an excerpt from the K10-form for the year 2006 for the calculation of the dividend allowance (Beräkning av gränsbelopp) under the simplification rule (Förenklingsregeln). The annual dividend allowance under the simplification rule (Årets gränsbelopp enligt förenklingsregeln) is defined as 64,950 SEK times the ratio of the number of own shares (Antal ägde andelar) to the number of total shares (Totala antalet andelar). The taxpayers fill in the field 410.

\section{Alternativ 1 - Förenklingsregeln}

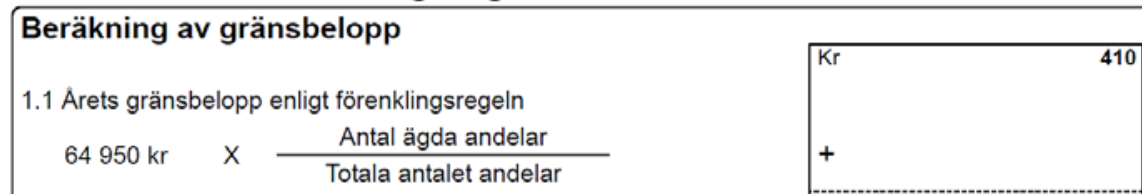

Figure 2: Frequencies of Excess Dividend Allowance Reporting, 2006-2009

This figure plots the frequencies of misreported dividend allowances in all our four sample years. On the horizontal axis, we use the ratio of claimed dividend allowance per firm to the maximum allowance per firm according to the tax law. A value above 1 is regarded as tax evasion by law. On the vertical axis, we use the frequency of cases in each bin.
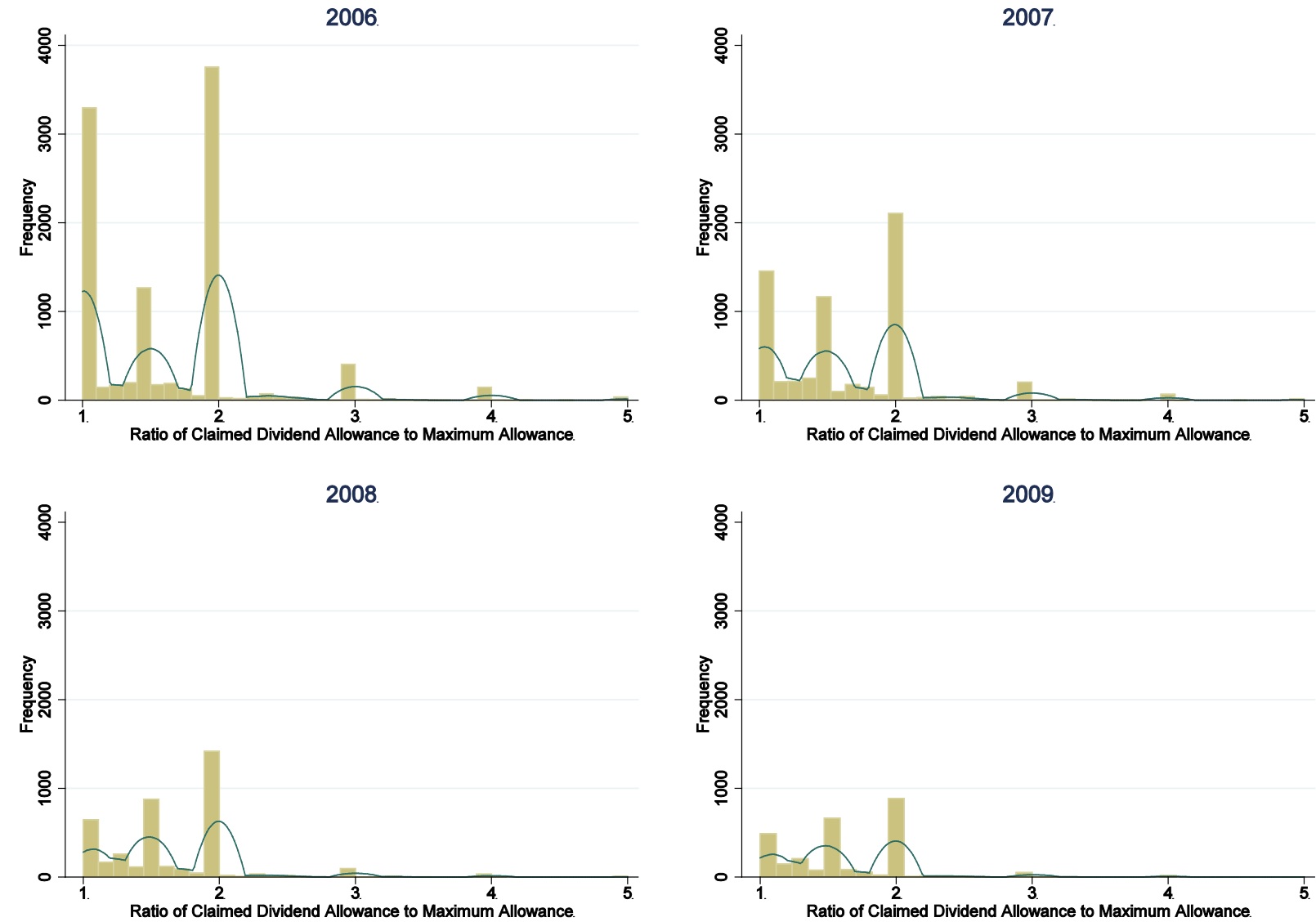
Figure 3: Self-Correction versus External correction

This figure plots the percentage of overstated dividend allowances in the preceding year (black bar), the percentage of cases that are detected (gray bar), the fraction of cases that are detected by the taxpayer (Self-Correction), and the percentage of cases that are detected by the tax authority (External Correction). The basis for the calculation for all four statistics is the total number K10-forms in a year.

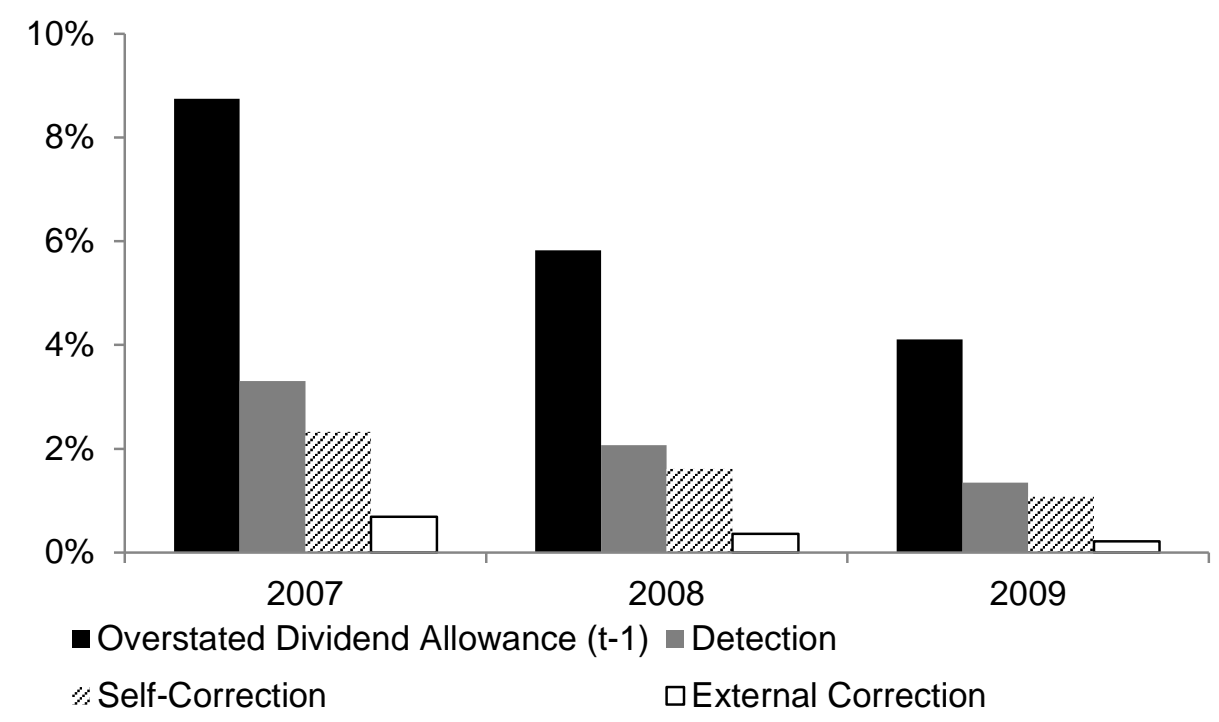


Table 1: Marginal tax rates and thresholds in Sweden, 2006-2009.

This table reports marginal tax rates on labor income and dividend income over the sample period. The marginal tax rate on labor income consists of a municipality tax (Local Tax, column 1, average over all municipalities), a government level tax of 20\% (State Tax Level 1) above the threshold reported in column (2), and a second level of state tax of 5\% above the threshold in column (3). In Column (4), we present the threshold at which the social security contributions (32.4\%) cease to generate benefits. Above the threshold the social security contributions we treat social security contributions on wage income (remitted at the coporate level) as a tax. The thresholds are reported in Swedish Krona (SEK). In 2006, USD 1 equals SEK 7.38. The combined marginal tax rate is presented in column (5). We neglect the standard deduction and the earned income tax credit in the calculation. In columns (6) to (7), we present the corporate tax rate on profits of closely held corporations (column 5), dividend taxes at the individual level (column 6), and the combined marginal tax rate on dividends, $\tau_{d}$, in column (7)

\begin{tabular}{|c|c|c|c|c|c|c|c|c|}
\hline \multirow[b]{2}{*}{ Year } & \multirow[b]{2}{*}{$\begin{array}{c}\text { Local } \\
\text { Tax }\end{array}$} & \multicolumn{4}{|c|}{ Labor Income } & \multicolumn{3}{|c|}{ Dividend Income from CHC } \\
\hline & & $\begin{array}{c}\text { State Tax } \\
\text { Level } 1 \text { of } \\
\text { 20\% above } \\
\text { (2) }\end{array}$ & $\begin{array}{l}\text { State Tax } \\
\text { Level } 2 \text { of } \\
5 \% \text { above } \\
\text { (3) }\end{array}$ & $\begin{array}{c}\text { Social } \\
\text { Security Tax } \\
\text { Threshold } \\
\text { (4) }\end{array}$ & (4) & $\begin{array}{l}\text { Corp. } \\
\text { Tax } \\
(5)\end{array}$ & $\begin{array}{l}\text { Dividend Tax } \\
\text { Individual } \\
\text { Level } \\
(6)\end{array}$ & $\tau_{d}$ \\
\hline 2006 & $31.6 \%$ & 317,700 & 472,300 & 359,100 & $31.6 \%-67.2 \%$ & $28.0 \%$ & $20 \%$ & $42.4 \%$ \\
\hline 2007 & $31.6 \%$ & 328,600 & 488,600 & 403,000 & $31.6 \%-67.2 \%$ & $28.0 \%$ & $20 \%$ & $42.4 \%$ \\
\hline 2008 & $31.4 \%$ & 340,900 & 507,100 & 410,000 & $31.4 \%-67.1 \%$ & $28.0 \%$ & $20 \%$ & $42.4 \%$ \\
\hline 2009 & $31.5 \%$ & 380,200 & 538,800 & 428,000 & $31.5 \%-66.9 \%$ & $26.3 \%$ & $20 \%$ & $41.0 \%$ \\
\hline
\end{tabular}

\section{Table 2: Tax Misreporting in the Dividend Allowance}

This Table illustrates the calculation of the dividend allowance in case of tax misreporting. The example assumes that no dividends are paid out. The maximum available allowance per firm is reported in Column 1. Column 2 and 5 illustrate the claimed dividend allowance by one active owner holding $50 \%$ of the shares. In Case 1 he claims twice the entitled allowance. In case of no detection, the current claimed allowance increases the total allowance at year end (Column $4=$ Column $3+2$ and Column $7=$ Column $6+5)$. The accumulated allowance in year t (Column 3 and 6 ) equals the compounded total dividend allowance from the preceding year from Column 4 and 7 . The interest rates are 6.54\% in 2007, 7.16\% in 2008, and 5.89\% in 2009.

\begin{tabular}{|c|c|c|c|c|c|c|c|}
\hline \multirow[t]{2}{*}{ Year } & \multirow{2}{*}{$\begin{array}{l}\text { Maximum } \\
\text { Allowance } \\
\text { in year } t\end{array}$} & \multicolumn{3}{|c|}{$\begin{array}{c}\text { Case 1: Misreporting of Allowance, } \\
\text { Share in CHC = 50\% }\end{array}$} & \multicolumn{3}{|c|}{$\begin{array}{c}\text { Case 2: Correct Reporting of } \\
\text { Allowance, Share in CHC = 50\% }\end{array}$} \\
\hline & & $\begin{array}{l}\text { Claimed } \\
\text { Current } \\
\text { Allowance } \\
\text { in year t } \\
\text { (2) }\end{array}$ & $\begin{array}{c}\text { Accumulated } \\
\text { Allowance in } \\
\text { year t from } \\
\text { last years } \\
\text { (3) }\end{array}$ & $\begin{array}{c}\text { Total } \\
\text { Allowance } \\
\text { at in end } \\
\text { of year t } \\
\text { (4) }\end{array}$ & $\begin{array}{c}\text { Claimed } \\
\text { Current } \\
\text { Allowance } \\
\text { in year t } \\
\text { (5) }\end{array}$ & $\begin{array}{l}\text { Accumulated } \\
\text { Allowance in } \\
\text { year t from } \\
\text { last years } \\
\text { (6) }\end{array}$ & $\begin{array}{l}\text { Total } \\
\text { Allowance } \\
\text { at in end } \\
\text { of year t } \\
\text { (7) }\end{array}$ \\
\hline 2006 & 64,950 & 64,950 & 0 & 64,950 & 32,475 & 0 & 32,475 \\
\hline 2007 & 89,000 & 89,000 & 69,198 & 158,198 & 44,500 & 34,599 & 79,099 \\
\hline 2008 & 91,800 & 91,800 & 169,525 & 261,325 & 45,900 & 84,762 & 130,662 \\
\hline 2009 & 120,000 & 120,000 & 276,717 & 396,717 & 60,000 & 138,358 & 198,358 \\
\hline
\end{tabular}




\section{Table 3: Self-Correction versus External correction}

This Table illustrates self-correction and external correction in mistakes in reporting the dividend allowance. The examples are based on Table 1. The active owner claims the current dividend allowance correctly for the first time in 2008 (values in bold fonts in Column 2 and 5). In Case 1, mistake is detected by the taxpayer (self-correction). That is, the excessive and unjustifiable total dividend allowance of preceding years is not corrected (value in italics in Column 3). Case 2 illustrates external correction. In this case the claimed dividend allowance of the last year is corrected and in the current year the correct recent dividend allowance is claimed (value in italics in Column 6).

\begin{tabular}{|c|c|c|c|c|c|c|c|}
\hline \multirow[t]{2}{*}{ Year } & \multirow{2}{*}{$\begin{array}{l}\text { Maximum } \\
\text { Allowance } \\
\text { in year } t\end{array}$} & \multicolumn{3}{|c|}{$\begin{array}{c}\text { Case 1: Self-Correction of Tax } \\
\text { Misreporting }\end{array}$} & \multicolumn{3}{|c|}{$\begin{array}{c}\text { Case 2: External correction of Tax } \\
\text { Misreporting }\end{array}$} \\
\hline & & $\begin{array}{c}\text { Claimed } \\
\text { Current } \\
\text { Allowance } \\
\text { in year t } \\
(2) \\
\end{array}$ & $\begin{array}{l}\text { Accumulated } \\
\text { Allowance in } \\
\text { year t from } \\
\text { last years } \\
\text { (3) }\end{array}$ & $\begin{array}{c}\text { Total } \\
\text { Allowance } \\
\text { at in end } \\
\text { of year t } \\
(4)\end{array}$ & $\begin{array}{c}\text { Claimed } \\
\text { Current } \\
\text { Allowance } \\
\text { in year t } \\
(5) \\
\end{array}$ & $\begin{array}{c}\text { Accumulated } \\
\text { Allowance in } \\
\text { year t from } \\
\text { last years } \\
(6)\end{array}$ & $\begin{array}{c}\text { Total } \\
\text { Allowance } \\
\text { at in end } \\
\text { of year t } \\
(7)\end{array}$ \\
\hline 2006 & 64,950 & 64,950 & 0 & 64,950 & 64,950 & 0 & 64,950 \\
\hline 2007 & 89,000 & 89,000 & 69,198 & 158,198 & 89,000 & 69,198 & 158,198 \\
\hline 2008 & 91,800 & 45,900 & 169,525 & 215,425 & 45,900 & 84,762 & 130,662 \\
\hline 2009 & 120,000 & 60,000 & 228,113 & 288,113 & 60,000 & 138,358 & 198,358 \\
\hline
\end{tabular}




\section{Table 4: Summary Statistics}

This table presents summary statistics for the sample of K10-forms for 2006-2009. Failure is a dummy variable equal to one if the dividend allowance is overreported. Self-Correction (External correction) is a dummy equal to one if prior year's failure is corrected and if the excess claimed dividend allowance is not corrected (is corrected as well). Both variables are defined for the 2007-2009 period only. Firm level controls include eight variables. Number Owners is the number of active owners in the firm. Different Region is a dummy equal to one if the owners of a corporation reside in different counties. Firm_Age is the age of the firm in year t. Dividend Payout is a dummy variable equal to one the firm $j$ pays out a dividend in year $t$. Ln(Assets) is the natural logarithm of the total assets in SEK. Return on Equity is the ratio of taxable profit at the CHC level in year $t$ divided by prior year's total book equity. Financial Assets is the ratio of financial assets and cash holdings at the CHC level in year $t$ divided by prior year's total assets. Shifting $\mathrm{CHC}$ is an indicator variable taking the value 1 if the CHC is a holding, shell or low-turnover corporation designed for tax avoidance (Alstadsæter and Jacob, 2013): We include thirteen individual level control variables. Number Firms is the number of firms owned by an individual. State Tax is a dummy variable equal to one if earned income (labor and business income) in the preceding year exceeds the threshold for the state tax of 20\%. Income Decile is the decile of the average income distribution of individual $i$ in year $t$. Age is the taxpayer's age in years. Born in Sweden is a dummy equal to one if the individual was born in Sweden. Female is a dummy variable equal to one if the taxpayer is female and zero otherwise. Married is a dummy variable equal to one if the taxpayer is married. Tertiary Education is a dummy variable equal to one if the individual holds a tertiary education degree of at least four years of college or university education. Business Degree is a dummy variable equal to one if the taxpayer holds a tertiary degree in business administration or economics. Law Degree (IT Degree) is a dummy variable equal to one if the individual has studied law (computer sciences). Rural Area is an indicator variable equal to one if the individual resides in a small village. City is an indicator variable equal to one if the individual resides in a city with a population of more than 10,000 persons.

\begin{tabular}{|c|c|c|c|c|c|c|}
\hline & $\mathbf{N}$ & Mean & $\begin{array}{l}\text { Standard } \\
\text { Deviation }\end{array}$ & $\begin{array}{c}10^{\text {th }} \\
\text { percentile }\end{array}$ & Median & $\begin{array}{c}90^{\text {th }} \\
\text { percentile }\end{array}$ \\
\hline \multicolumn{7}{|c|}{ Panel A: Misreporting Variables } \\
\hline Failure & 576,916 & 0.050 & 0.217 & 0.000 & 0.000 & 0.000 \\
\hline Self-Correction & 475,038 & 0.018 & 0.134 & 0.000 & 0.000 & 0.000 \\
\hline External correction & 475,038 & 0.007 & 0.081 & 0.000 & 0.000 & 0.000 \\
\hline \multicolumn{7}{|c|}{ Panel B: Independent Variables } \\
\hline \multicolumn{7}{|c|}{ Firm Level Variables } \\
\hline Number Owners & 576,916 & 1.904 & 1.027 & 1.000 & 2.000 & 3.000 \\
\hline Different Region & 576,916 & 0.071 & 0.257 & 0.000 & 0.000 & 0.000 \\
\hline Firm_Age & 576,916 & 14.880 & 11.390 & 3.000 & 14.000 & 27.000 \\
\hline Dividend Payout & 576,916 & 0.380 & 0.485 & 0.000 & 0.000 & 1.000 \\
\hline Ln(Assets) & 576,916 & 14.140 & 1.354 & 12.440 & 14.120 & 15.860 \\
\hline Return on Equity & 576,916 & 0.067 & 0.467 & -0.354 & 0.025 & 0.397 \\
\hline Financial Assets & 576,916 & 0.406 & 0.356 & 0.011 & 0.311 & 0.985 \\
\hline Shifting CHC & 576,916 & 0.145 & 0.352 & 0.000 & 0.000 & 1.000 \\
\hline \multicolumn{7}{|c|}{ Individual Level Variables } \\
\hline Number Firms & 576,916 & 1.256 & 0.646 & 1.000 & 1.000 & 2.000 \\
\hline State Tax & 576,916 & 0.446 & 0.497 & 0.000 & 0.000 & 1.000 \\
\hline Income Decile & 576,916 & 4.967 & 2.751 & 1.000 & 5.000 & 9.000 \\
\hline Age & 576,916 & 51.610 & 11.870 & 36.000 & 52.000 & 66.000 \\
\hline Born in Sweden & 576,916 & 0.928 & 0.259 & 1.000 & 1.000 & 1.000 \\
\hline Female & 576,916 & 0.238 & 0.426 & 0.000 & 0.000 & 1.000 \\
\hline Married & 576,916 & 0.631 & 0.483 & 0.000 & 1.000 & 1.000 \\
\hline Tertiary Education & 576,916 & 0.194 & 0.396 & 0.000 & 0.000 & 1.000 \\
\hline Business Degree & 576,916 & 0.161 & 0.368 & 0.000 & 0.000 & 1.000 \\
\hline Law Degree & 576,916 & 0.017 & 0.129 & 0.000 & 0.000 & 0.000 \\
\hline IT Degree & 576,916 & 0.011 & 0.105 & 0.000 & 0.000 & 0.000 \\
\hline Rural Area & 576,916 & 0.171 & 0.377 & 0.000 & 0.000 & 1.000 \\
\hline City & 576,916 & 0.708 & 0.455 & 0.000 & 1.000 & 1.000 \\
\hline
\end{tabular}


Table 5: The Likelihood of Overstating the Dividend Allowance

This table reports regression results from OLS regressions over the 2006-2009 period. The dependent variable is a nominal variable taking the value 1 if the dividend allowance is overstated, and 0 otherwise. Independent variables cover all variables from Panel B of Table 3. We report robust standard errors (s.e.) clustered at the individual level. $* * *, * *$, and $*$ denote significance at the $1 \%, 5 \%$, and $10 \%$ levels, respectively.

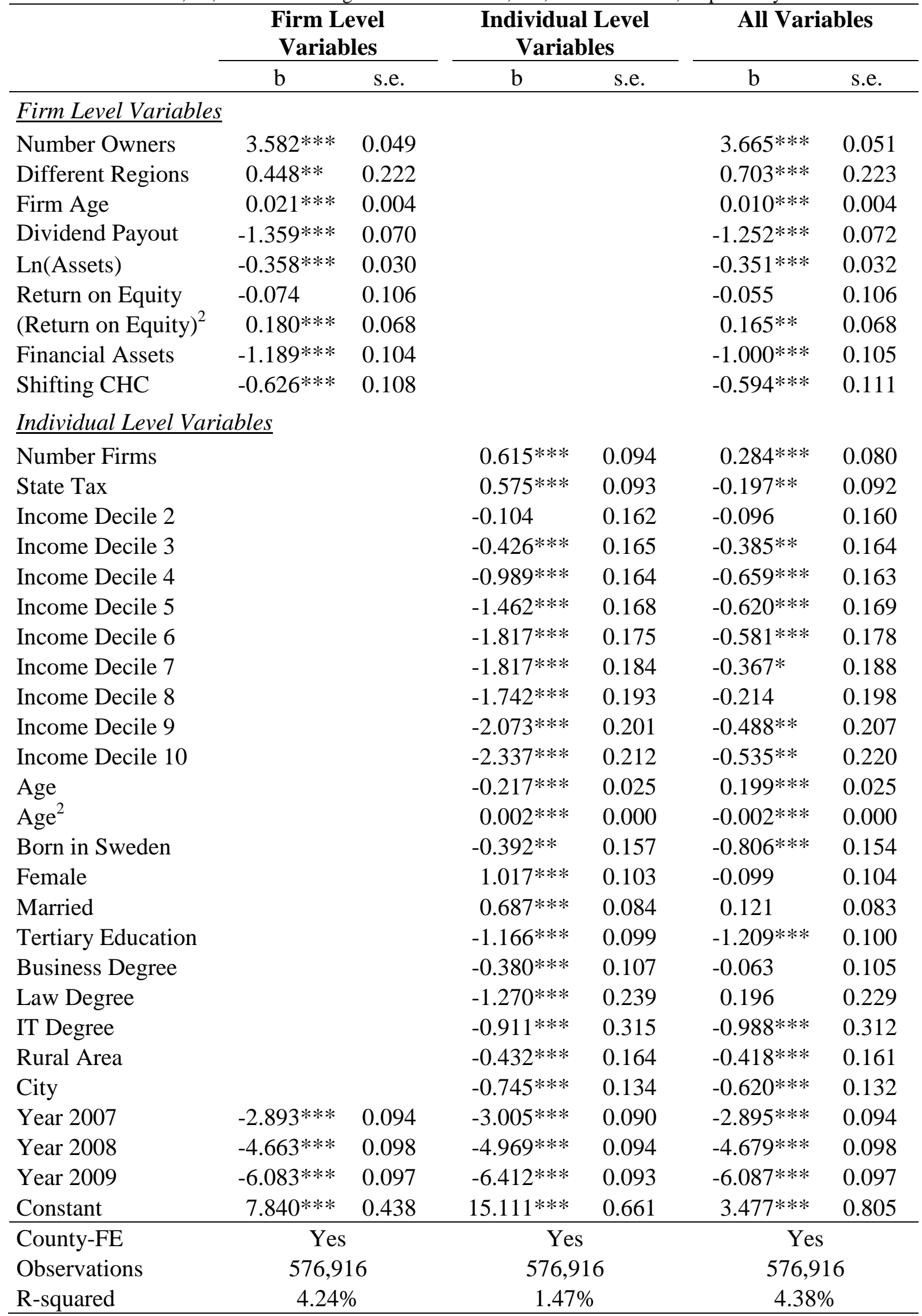




\section{Table 6: Tax Incentives, Tax Awareness, and Overstating Dividend Allowances: Local Linear Regressions}

This table presents local linear regression results around the major kink in the marginal tax rate. We use the dummy variable Failure as dependent variable. The range is defined in SEK around the first state tax threshold. Individuals above this threshold are subject to the $20 \%$ state tax. We present coefficient estimates for a dummy equal to one if the individual was above this threshold. We use a range of SEK 1,000 (Columns 1 to 3) and SEK 500 (Columns 4 to 6) around the state tax threshold. We present results without controls in Panel A. Panel B presents coefficient estimates for crossing the state tax threshold with control variables. Independent variables cover all variables from Panel B of Table 3. In Column (2) and (5), we restrict the sample to individuals born in Sweden. Column (3) and (6) uses individuals born outside of Sweden. Standard errors (shown in parentheses) allow for heteroskedasticity. ***, **, and * denote significance at the $1 \%, 5 \%$, and $10 \%$ levels, respectively.

\begin{tabular}{|c|c|c|c|c|c|c|}
\hline \multicolumn{7}{|c|}{ Panel A: Local Linear Regression Without Controls } \\
\hline & \multicolumn{3}{|c|}{ SEK 1,000 around Threshold } & \multicolumn{3}{|c|}{ SEK 500 around Threshold } \\
\hline & Full & Born in & Born & Full & Born in & Born \\
\hline & $\begin{array}{c}\text { Sample } \\
\text { (1) }\end{array}$ & $\begin{array}{c}\text { Sweden } \\
\text { (2) }\end{array}$ & $\begin{array}{l}\text { Abroad } \\
\text { (3) }\end{array}$ & $\begin{array}{c}\text { Sample } \\
\text { (4) }\end{array}$ & $\begin{array}{c}\text { Sweden } \\
\text { (5) }\end{array}$ & $\begin{array}{c}\text { Abroad } \\
\text { (6) }\end{array}$ \\
\hline \multirow[t]{2}{*}{ State Tax } & $1.725 * * *$ & $1.784^{* * *}$ & 0.465 & $1.993 * * *$ & $2.497 * * *$ & -4.950 \\
\hline & $(0.626)$ & $(0.638)$ & (3.002) & $(0.707)$ & $(0.728)$ & (3.086) \\
\hline Controls & No & No & No & No & No & No \\
\hline Year-FE & No & No & No & No & No & No \\
\hline County-FE & No & No & No & No & No & No \\
\hline Observations & 3,627 & 3,390 & 237 & 2,409 & 2,244 & 165 \\
\hline \multicolumn{7}{|c|}{ Panel B: Local Linear Regression With Controls } \\
\hline State Tax & $1.348 * *$ & $1.351^{* *}$ & 1.711 & $1.582^{* *}$ & $1.972 * * *$ & -2.757 \\
\hline & $(0.611)$ & $(0.624)$ & $(3.416)$ & $(0.671)$ & $(0.689)$ & $(3.262)$ \\
\hline Controls & Yes & Yes & Yes & Yes & Yes & Yes \\
\hline Year-FE & Yes & Yes & Yes & Yes & Yes & Yes \\
\hline County-FE & Yes & Yes & Yes & Yes & Yes & Yes \\
\hline Observations & 3,627 & 3,390 & 237 & 2,409 & 2,244 & 165 \\
\hline
\end{tabular}

Table 7: Tax Incentives, Complexity, and Overstating Dividend Allowances

This table presents local linear regression results around the major kink in the marginal tax rate. We use the dummy variable Failure as dependent variable. The range is defined in SEK around the first state tax threshold. Individuals above this threshold are subject to the $20 \%$ state tax. We present coefficient estimates for a dummy equal to one if the individual was above this threshold. We use a range of SEK 1,000 (Columns 1 to 3) and SEK 500 (Columns 4 to 6) around the state tax threshold. We present results without controls in Panel A. Panel B presents coefficient estimates for crossing the state tax threshold with control variables. Independent variables cover all variables from Panel B of Table 3. In Column (1) and (3), we restrict the sample to CHCs with two active owners. Column (2) and (4) uses CHCs with more than two active owners. Standard errors (shown in parentheses) allow for heteroskedasticity. $* * *, * *$, and * denote significance at the $1 \%, 5 \%$, and $10 \%$ levels, respectively.

\begin{tabular}{|c|c|c|c|c|}
\hline \multicolumn{5}{|c|}{ Panel A: Local Linear Regression Without Controls } \\
\hline & \multicolumn{2}{|c|}{ SEK 1,000 around Threshold } & \multicolumn{2}{|c|}{ SEK 500 around Threshold } \\
\hline & $\begin{array}{c}2 \text { Owners } \\
\text { (1) }\end{array}$ & $\begin{array}{c}>2 \text { Owners } \\
\text { (2) }\end{array}$ & $\begin{array}{c}2 \text { Owners } \\
\text { (3) }\end{array}$ & $\begin{array}{c}>2 \text { Owners } \\
\text { (4) }\end{array}$ \\
\hline State Tax & $\begin{array}{c}3.508 * * \\
(1.424)\end{array}$ & $\begin{array}{c}2.740 \\
(2.667)\end{array}$ & $\begin{array}{c}4.588^{* * *} \\
(1.684)\end{array}$ & $\begin{array}{c}2.095 \\
(3.506)\end{array}$ \\
\hline Controls & No & No & No & No \\
\hline Observations & 1,194 & 532 & 767 & 302 \\
\hline \multicolumn{5}{|c|}{ Panel B: Local Linear Regression With Controls } \\
\hline State Tax & $\begin{array}{l}2.611^{*} \\
(1.410) \\
\end{array}$ & $\begin{array}{c}2.420 \\
(2.586) \\
\end{array}$ & $\begin{array}{c}1.725^{* *} \\
(0.762) \\
\end{array}$ & $\begin{array}{c}2.261 \\
(3.397) \\
\end{array}$ \\
\hline Controls & Yes & Yes & Yes & Yes \\
\hline Observations & 1,194 & 532 & 767 & 303 \\
\hline
\end{tabular}


Table 8: Determinants of Self-Correction and External Correction

This table reports regression results from Cox proportional hazards model with time-varying co-variates over the 2007-2009 period. The dependent variable is time-to-self-correction (Panel A), and time-to-external-correction (Panel B). Independent variables cover all variables from Panel B of Table 3. Standard errors (s.e.) allow for heteroskedasticity. ${ }^{* *}, * *$, and $*$ denote significance at the $1 \%, 5 \%$, and $10 \%$ levels, respectively. The sample consists of 475,038 observations.

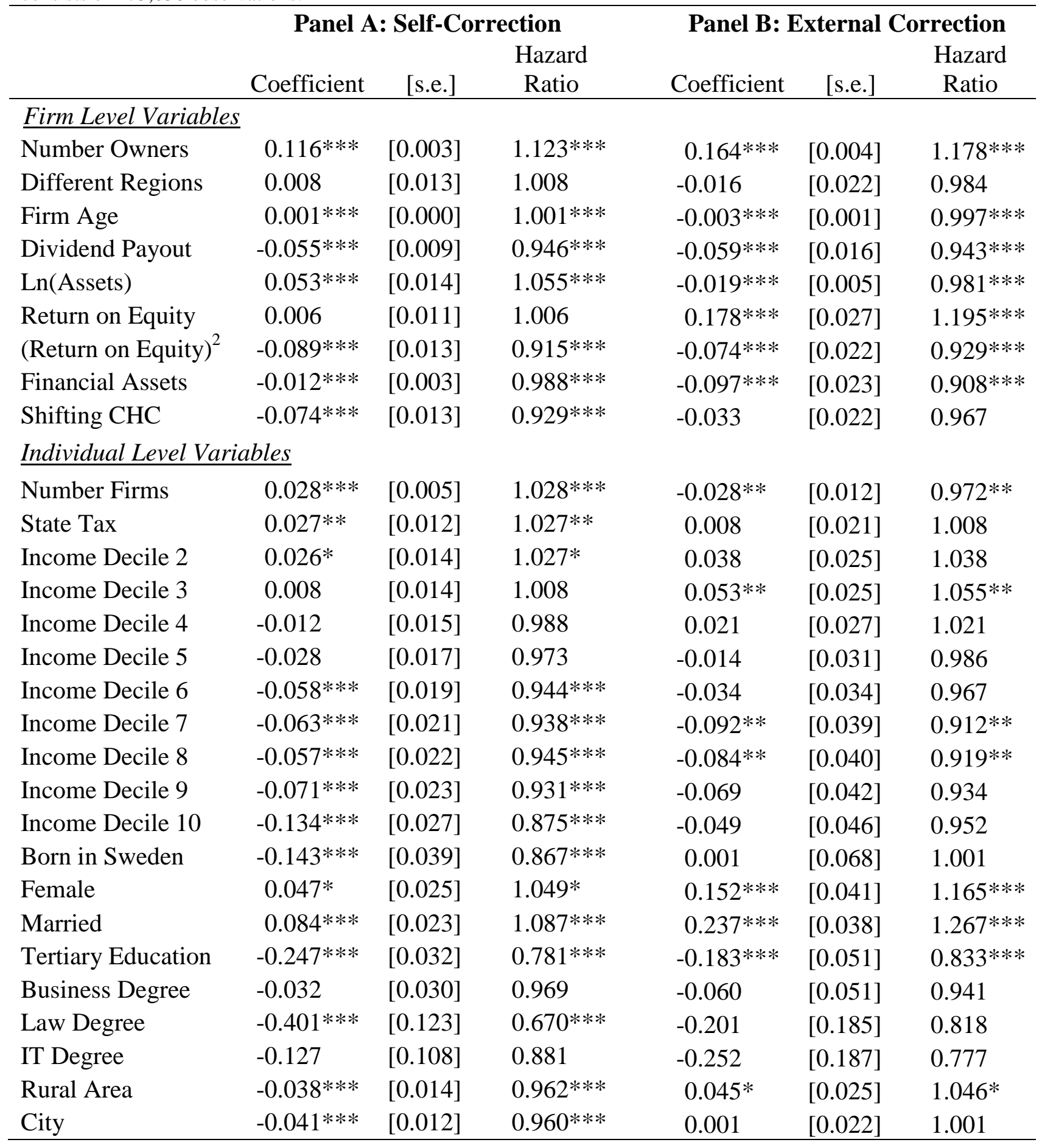

